JAZZ IN SEARCH OF ITSELF 



\section{LARR KART}

\section{Jazz in Search of Itself}

Yale University Press NEW HAVEN AND LONDON 


\section{FOR JACOB}

Published with assistance from the Louis Stern Memorial Fund.

Copyright (c) 2004 by Yale University. All rights reserved. This book may not be reproduced, in whole or in part, including illustrations, in any form (beyond that copying permitted by Sections 107 and 108 of the U.S. Copyright Law and except by reviewers for the public press), without written permission from the publishers.

Set in Minion type by Binghamton Valley Composition.

Printed in the United States of America.

Library of Congress Cataloging-in-Publication Data

Kart, Larry, 1942-

Jazz in search of itself / Larry Kart.

p. $\mathrm{cm}$.

Includes index.

ISBN 0-300-10420-0 (cloth : alk. paper)

1. Jazz-History and criticism. I. Title.

ML3506.K37 2004

$781.65^{\prime} 09-d c 22$

2004041413

A catalogue record for this book is available from the British Library.

The paper in this book meets the guidelines for permanence and durability of the Committee on Production Guidelines for Book Longevity of the Council on Library Resources.

$\begin{array}{llllllllll}10 & 9 & 8 & 7 & 6 & 5 & 4 & 3 & 2 & 1\end{array}$

The following pieces were first published in the Chicago Tribune and appear here by permission: Johnny Griffin; Ira Sullivan; Louis Armstrong; Black Beauty, White Heat; Earl Hines; Count Basie; Duke Ellington; Arthur Rollini; Arnett Cobb; Artie Shaw; Louis Bellson; Ruby Braff; Dizzy Gillespie; Thelonious Monk; Herbie Nichols; Oscar Peterson; Stan Getz; Woody Herman and Stan Getz; Al Cohn; Art Pepper; Sonny Stitt; Jackie McLean; Clifford Brown and Max Roach; Philly Joe Jones; Horace Silver; Bill Evans; Keith Jarrett; Gary Burton; Pat Metheny; McCoy Tyner; Wayne Shorter; Ornette Coleman; Cecil Taylor; Roscoe Mitchell; Evan Parker; Village Vanguard Jazz Orchestra; Milestones; Miles Returns; Lee Konitz; Marsalis at Twenty-One; The Death of Jazz?; "The Death of Jazz?" Revisited; The Marsalis Brothers Further On; The Sound-Alikes; Gershwin Musicals; Hoagy Carmichael; Smithsonian Pop; Billie Holiday; Sarah Vaughan; Cabaret Music; Chris Connor; Tony Bennett; The Jazzman as Rebel; Anita O'Day; Jazz Goes to College.

The following pieces were first published in Down Beat magazine and appear here by permission: Notes and Memories of the New Music; Lee Morgan, Donald Byrd, Blue Mitchell; Frank Zappa; Miles in the Sky; In a Silent Way; The Lost Quintet; Jazz in the Global Village; Raiders of the Lost Art.

An excerpt from The Oxford Companion to Jazz appears here by permission of Oxford University Press.

Jazz and Jack Kerouac first appeared in The Review of Contemporary Fiction. 